\title{
DESCRIBING VEGETATION AT THE LANDSCAPE LEVEL: "PAYSAGE", A DATABASE DESIGNED FOR SERIES AND GEOSERIES DATASETS
}

\author{
Camille ROUX', Gilles THÉBAUD ${ }^{1}$, Jan-Bernard BOUZILLÉ ${ }^{2}$, Anne BONIS ${ }^{2}$, Stephan HENNEKENS \\ ${ }^{1}$ UNIVEGE, Université Blaise Pascal, 3 Bd Lafayette, F-63000 Clermont-Ferrand, France \\ ${ }^{2}$ UMR ECOBIO, CNRS-University of Rennes 1, F-Rennes, France \\ ${ }^{3 .}$ ALTERRA WUR, Wageningen, the Netherlands \\ e-mail: camille.roux@univ-bpclermont.fr,
}

\begin{abstract}
The CarHAB project, funded by the French Ministry of Environment, was set up to map the vegetation all over the French territory. In this objective, both analytical (plot) relevés and synrelevés were carried out. Based on the case study of low mountain habitats in the "chaine des Puys" (Massif central, France), this paper presents i) the methodology developed to carry out vegetation relevés at the landscape scale and ii) the database designed to store and fit synrelevés, as part of the national VegFrance database.

This paper presents the structure of the "Paysage" database, the metadata collected together with plants communities in the synrelevés (and geosynrelevés), the method to record the synrelevés and how they are managed for the mapping of series and geoseries. The interpretation of the dataset regarding anthropic pressure on this landscape will be suggested.
\end{abstract}

Keywords: symphytosociology; lanscape; database; VegFrance; Turboveg; Clermont-Ferrand

\section{Introduction}

The public authorities are becoming increasingly concerned about the preservation and restoration of ecosystems (Rio de Janeiro Convention on Biological Diversity, European Habitats Directive 92/43/CEE). Accordingly, there is thus a clear need to describe and acknowledge the biodiversity of regions. Only with this knowledge can there be a "reflection on the future of the natural habitats on one side, and (...) a spatial modelling of environmental patterns in a prospective meaning, on the other" (Trochet 2004). It is within this context that the Ministry of Ecology and Sustainable Development (MEDDE) launched a mapping program for the French natural and semi-natural habitats (CarHAB), including a "Paysage" section. This program is set up to provide maps of the vegetation in continental France at a scale of 1 to 25,000, and thereafter knowledge regarding the phytoecological characterization of protected areas. This information is of upmost importance for designing the maintenance and restoration of the ecological connectivity and needs to be taken into account in the early stages of any infrastructure planning, notably with respect to the green and blue network.

Phytosociology represents an efficient method to describe, map and evaluate the conservation status of a landscape in terms of habitat, when it is paired with a geomorphological, physionomical and dynamic approach [11]. Synphytosociological information is essential to carry out sustainable management in order to preserve biodiversity [16]. At the landscape level, "synphytosociology" allows to identify the ecological variables determining the landscape. 
Together with the potential dynamics of the habitats, this approach provides meaningful information to rationalize their management. Synphytosociology is an approach allowing to characterize and map the potential natural vegetation (PNV) may have developed without any human impact [26, 21] as well as after all anthropogenic influences stopped [13, 3]. Its purpose is to determine a scenario of natural evolution of the vegetation under the influence of environmental factors and also to provide an ecological description of the areas considered [17]. The synphytosociological approach can also be used to characterize the potential replacement vegetation (PRV) [7] and thereafter evaluate its remoteness from the present vegetation. This type of evaluation is an essential indicator for the management of landscapes $[3,18]$.

Synrelevés are relevés of syntaxa within a given vegetation succession in a homogeneous ecological spatial unit (series), that is an area in which only one type of potential vegetation (series of vegetation) is expected. A complementary approach consists in the performance of geosynrelevés, which consist of relevés of syntaxa spread along an ecological gradient while in a given geomorphological unit (geoseries).

The Clermont-Ferrand region (Massif central, France) was selected as a pilot site for the characterization and mapping of the series and geoseries. The aim is to test the national methodology (Bioret et al. this volume), based on the synphytosociology. As a test site, this work focused on low mountain habitats.

For this study, a dedicated "Paysage" database was designed and set up as part of the national VegFrance database (http://vegfrance.univ-rennes1.fr). It can be used to integrate data corresponding to "synrelevés", i.e. relevés of syntaxa (plant communities).

This article presents the type of data that will be integrated in this database, the structure of the database as well as examples of application.

\section{Definition}

The main concepts and definitions of the synphytosociological method are explained in detail by Bioret et al. (2016; this volume).

For the synphytosociology, field relevés consist of carrying out relevés of the syntaxa, considering every syntaxa existing in a homogeneous ecological spatial framework (i.e. a tessela). A homogeneous ecological spatial framework corresponds to an area in which only one type of potential vegetation (series of vegetation $=$ sigmassiociation) is expected. The criteria for this type of delimitation is the unicity of the head of the series, either the natural potential vegetation or the potential replacement vegetation depending on the degree of anthropization. Anthropogenic influence may block the vegetation at certain stages but the vegetation succession may generally resume when the influence ceases.

The series is generally composed of several syntaxa which each represent a dynamic stage. Each syntaxon recorded in the relevé is given a coefficient of abundance, proportional to its relative spatial extent.

Geosynrelevés are relevés of syntaxa in a geomorphological and bioclimatic unit of variable size [23], composed of one or several series of vegetation (i.e. catena). 


\section{Development of the Dataset}

The first step of this work was to identify each ecological unit and its geographical limits in order to delineate the area concerned by a synrelevé, in a tessela. This was done by considering ecological variables such as altitude, geological nature of the substrate, elevation, and aspect and thereafter delimiting areas with homogeneous values for these variables. The goal of the second is to establish a list of plant associations occurring in the study area [22] and is carried out by reviewing the literature for phytosociological data as well as for vegetation dynamics. The relevés found in the literature are thereafter recorded in a geographical information system. For the the chaine des Puys, 766 relevés were recorded in situ and 5000 were collected from the literature.

The third step was to record synrelevés in the field. The plant associations of a synrelevé are assigned a coefficient of abundance and they are located and delineated [12]. Ortho-photos are useful documents to complement the field data and to evaluate the abundance coefficients for each syntaxon. Some synrelevés were carried out or complemented with a geographical information system (GIS) that contains both relevés and a variety of ecological information such as the geology, the aspect, as well as the topographical lines obtained from a digital terrain model. A total of 126 synrelevés were carried out on the 53,000 hectares of the study area.

\section{The symphytosociogical data (synrelevés)}

The 126 synrelevés were analyzed using the JUICE software together with a manual diagonalization (Table 1). With regards to the numerical analyses, a Canonical Correspondence Analysis (Ter Braak 1986) was used in order to characterize and describe the series and geoseries occurring in the study area. The Turboveg software [14] allows us to export the synphytosociological data in several formats in order to perform the data analysis using the JUICE software [24].

Twenty six series and 16 geoseries were identified (Table 1).

Hereafter, we will consider the Polygonatum multiflorum and Sorbus aria beech woods series (Polygonato multiflori-Fageto sylvaticae sorbesoto ariae sigmetum) as an example.

Based on the 15 synrelevés carried out for this series of vegetation units (grey part in Table 1), we were able to create a flowchart (Figure 1). This flowchart shows the syntaxa (i.e. plant associations or sub-associations) that correspond to each dynamic stage of the vegetation. From left to right, the vegetation units (associations) change from grasslands/heathlands, herbaceous fringes/scrubs, to shrublands, and to forests. Two succession patterns are distinguished, which depend on the degree of anthropogenic impact on the vegetation: the most "natural" succession (upper part of Figure 1) and the replacement vegetation following soil improvement as the main anthropogenic impact in this example.

This series is also characterized by the geographical and ecological parameters of its tessela: it is climatophilous, submontain and is characterized by oligotrophic to mesotrophic soil. It shows mesophilous flora that are moderately acidic in agreement with the crystalline rock bed. 
Table 1: Table of the synrelevés carried out. Each line is a syntaxon, the code for the series to which the syntaxon is related is indicated in the columns. The Polygonatum multiflorum and Sorbus aria beech wood synrelevés used as a case study in this paper are shaded in grey.

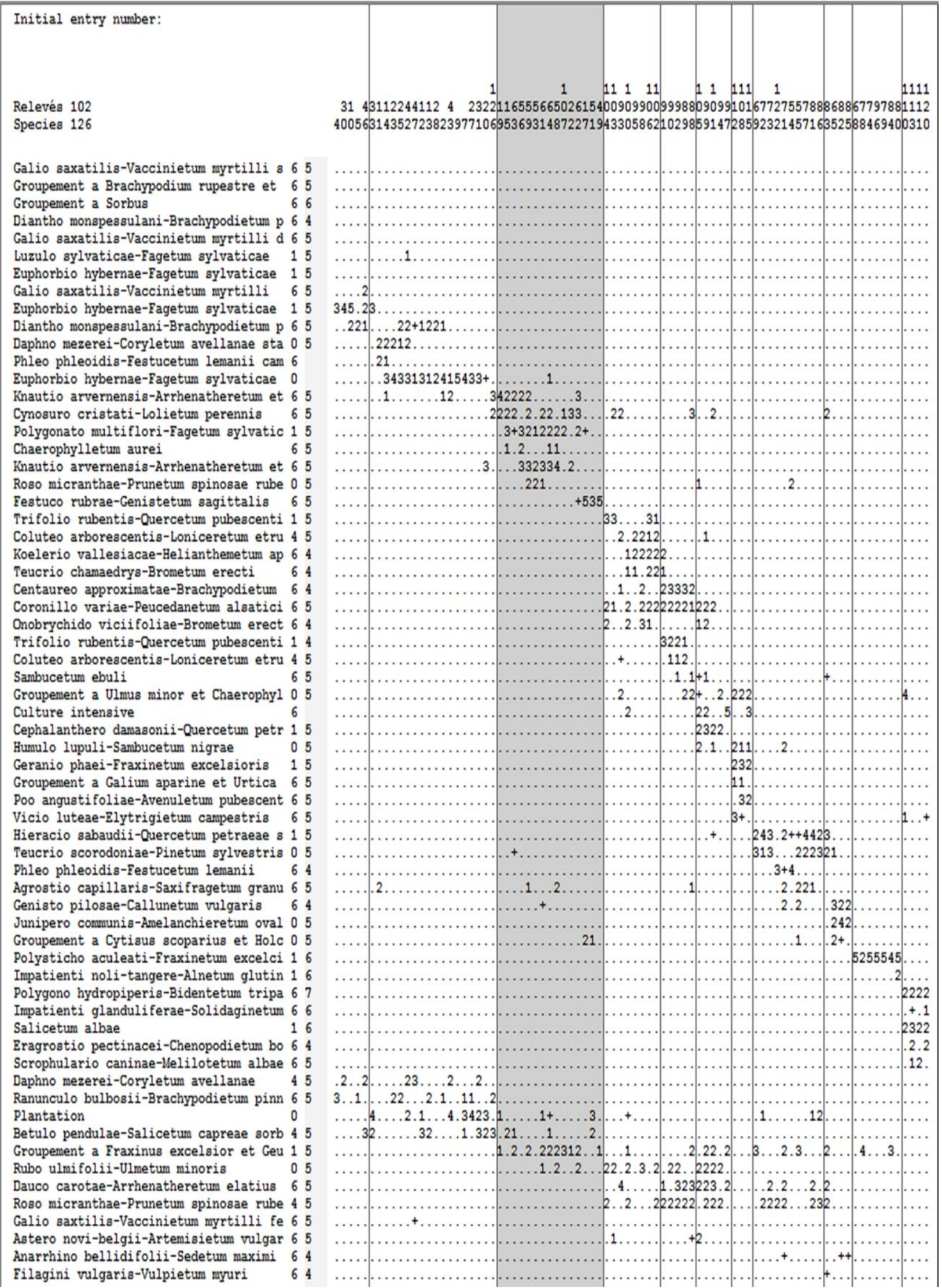




\section{Polygonato multiflori-Fageto sylvaticae sorbetoso ariae sigmetum \\ Climatophilous serie, submontane level, oligotrophic to mesotrophic, xerophylous to mesophilous, moderately acidic, on granite, of crystalline plateau}

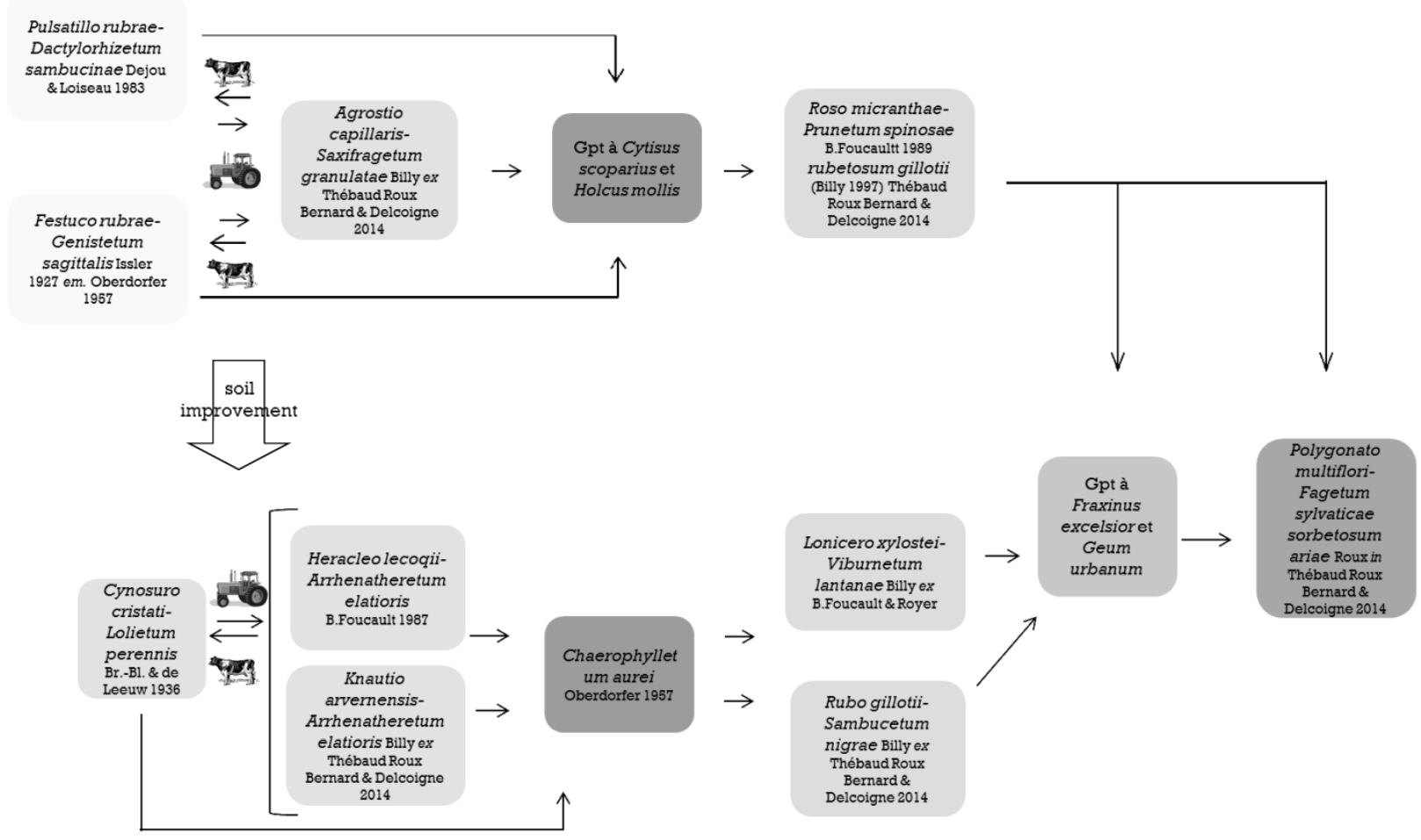

Fig. 1: Flow diagram of the Polygonatum multiflorum and Sorbus aria beech wood series. At the top: "natural vegetation dynamics with extensive grasslands"; at the bottom: anthropogenic-related succession with intensive grassland management. From left to right: grasslands/heaths, herbaceous fringes/scrubs, shrublands, pioneer forests and mature forest

\section{Description of the "Paysage" database}

The "Paysage" database is made up of two main tables: the syntaxon table (vegetation part) and the "header-data" table for the other data. Table 2 presents the two kinds of information for two synrelevés, no. 17 and no. 22.

\section{Syntaxa data stored in the Paysage database using the Turboveg software}

Figure 2 is a screen capture of the "syntaxon" table in the Turboveg "Paysage" database. Within each synrelevé (cf. Table 2), a list of the syntaxa is used to describe the vegetation. This list replaces the usual list of species used in an analytical relevé. The syntaxa list consists of vegetation associations, sub-associations, variants and eventually undefined vegetation units (left frame, Figure 2). The syntaxa list is composed of plant communities from the "Prodrome des Végétations de France" (PVF2, [2] together with the syntaxa described in Thébaud et al. (2014) in the study sites. In Figure 2, the frame on the right side presents an example of a synrelevé carried out in the Polygonatum multiflorum and Sorbus aria beech wood series, with a column for the vegetation layer, and a column for the coefficient of abundance-dominance for the syntaxon ("Cover"). 
Table 2: Example of a dataset in the "Paysage" database composed of two synrelevés (no. 17 and 22) relative to the Polygonatum multiflorum and Sorbus aria beech wood series. This figure is a screen capture from the Paysage database in Turboveg.

\begin{tabular}{|c|c|c|c|}
\hline $\mathrm{N}^{\circ}$ synrelevé & & 17 & 22 \\
\hline Code de l'auteur & & Roux C. & Roux C. \\
\hline Identifiant polygone SIG & & 25 & 31 \\
\hline Pays & & $\mathrm{FR}$ & $\mathrm{FR}$ \\
\hline Région phyto-écologique & & X.D29: Rebord occidental des Limagnes & X.D29: Rebord occidental des Limagnes \\
\hline Localite & & Saint-Aubin & Laschamps \\
\hline Surface du synrelevé (ha) & & 273 & 367 \\
\hline Altitude $(\mathrm{m})$ & & 960 & 950 \\
\hline Type de série & & Climatophile & Climatophile \\
\hline Nom de la série & & PM-FS-S & PM-FS-S \\
\hline Forme de la série & & Etendue & Etendue \\
\hline Réaction acido-basique du sol & & acidicline à neutrocline & acidicline à neutrocline \\
\hline Gradient hydrique & & mésophile & mésophile \\
\hline Nutriments & & oligomésotrophe & mésoeutrophe \\
\hline Substrat géologique & & Cristallin & Cristallin \\
\hline Pédologie & & Brunisol & Brunisol \\
\hline Eclairement & & hémihéliophile & hémisciaphile à hémihéliophile \\
\hline Température & & mésothermophile, submontagnard tempéré & $\begin{array}{l}\text { mésothermophile, submontagnard } \\
\text { tempéré }\end{array}$ \\
\hline Continentalité & & subocéanique & subocéanique \\
\hline & & & \\
\hline Festuco rubrae-Genistetum sagittalis & hl & 5 & \\
\hline Polygonato multiflori-Fagetum sylvaticae sorbetosum aria & t1 & 1 & \\
\hline Groupement à Cytisus scoparius et Holcus mollis & s1 & $2 a$ & \\
\hline Agrostio capillaris-Saxifragetum granulatae & hl & & \\
\hline Pulsatillo rubrae-Dactylorhizetum sambucinae & hl & & \\
\hline Cynosuro cristati-Lolietum perennis & hl & & 3 \\
\hline Heracleo lecoqii-Arrhenatheretum elatioris heracleetosum & hl & & $2 a$ \\
\hline Knautio arvernensis-Arrhenatheretum etlatioris malvetosu & hl & & $2 b$ \\
\hline Chaerophylletum aurei & hl & & 1 \\
\hline Groupement à Fraxinus excelsior et Geum urbanum & $\mathrm{t} 1$ & & 1 \\
\hline
\end{tabular}

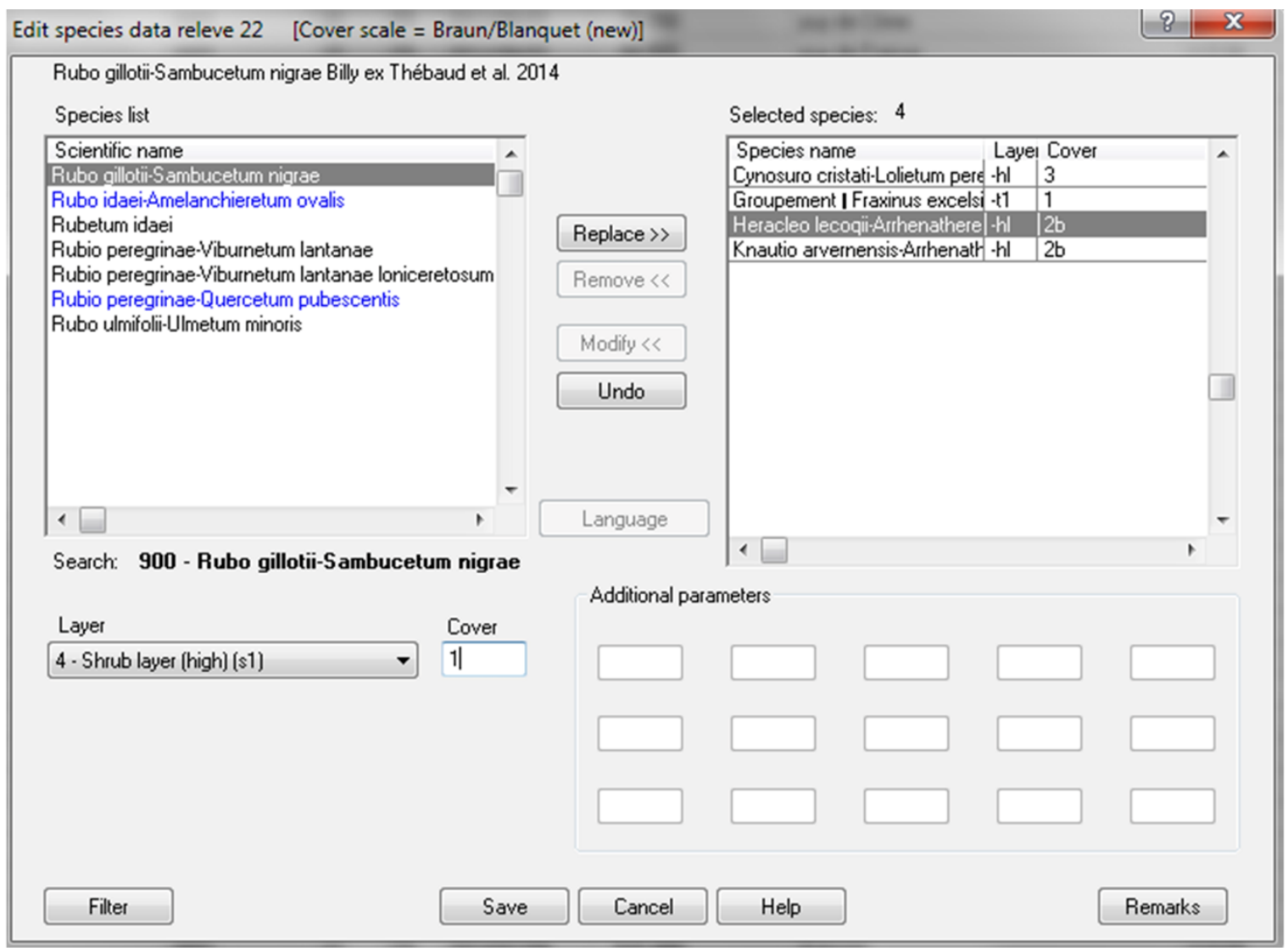

Fig. 2: Synrelevés in the Turboveg software. The syntaxa are chosen from a pop-up list on the left frame entitled "species list" in reference to the analytical relevés. The right side of the window shows the selected syntaxa for synrelevé 22 (the Polygonatum multiflorum and Sorbus aria beech wood series). 
Metadata in the synrelevés stored in the Paysage database using the Turboveg software

Metadata relative to each synrelevé may be indicated using the plot-based structure of the "Header-data" table from the original Turboveg software (Figure 3). They refer to the "cover abundance scale", "author code", "country code", "reference", "table number", "number in table", "project", "date", "surface", "altitude", "aspect", "inclination", and the cover of the different vegetation layers.

Other metadata are specific to the VegFrance-Paysage database, such as the "data distribution plan" and "provider of the synrelevé".

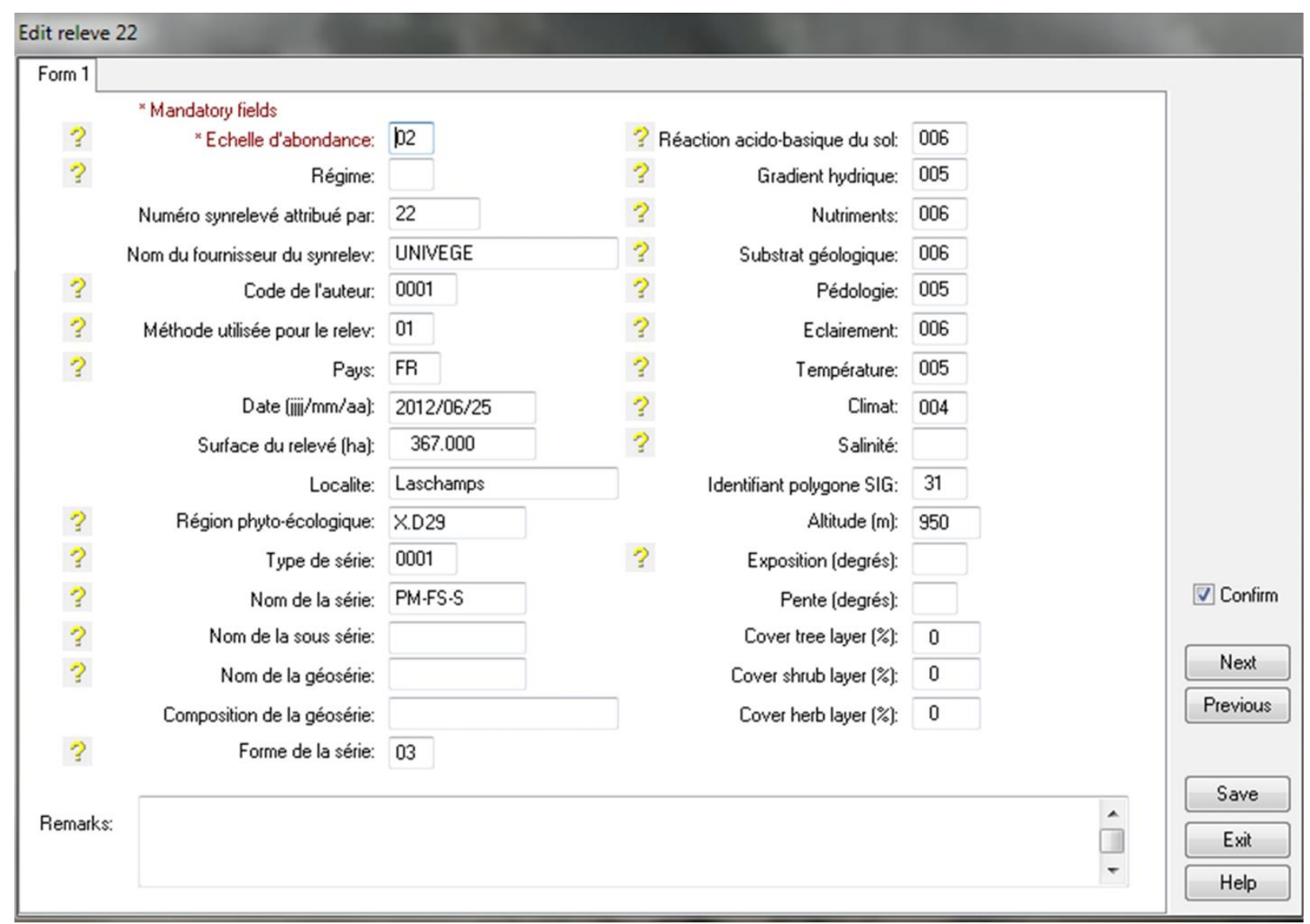

Fig. 3: Metadata specific to the Paysage database, characterizing each synrelevé. This example shows synrelevé no. 22 for the Polygonatum multiflorum and Sorbus aria beech wood series.

Metadata specific to the Paysage database may also be indicated in the dedicated Turboveg tool (see Figure 3) as the following information:

- "Method used for the relevé": this may be used to specify whether the data concerns a synrelevé or a geosynrelevé, or describes a certain area such as a paddock.

- "Phytoecological region": this refers to the French classification of the phyto-ecological regions provided by Dupias and Rey (1985).

- "Type of series": this is used to characterize the series depending on the ecological situation: climatophilous, edaxerophilous, edaphoygrophilous, curtaseries, permaseries $[19,20,16$ and Bioret et al. this volume). 
- "Name of the series", "Name of the sub-series" or "Name of the geoseries": this corresponds to the reference code of the series defined in this work in the study area, (PM-FS-S for the Polygonato multiflori-Fageto sylvaticae sorbetoso ariae sigmetum)

- "Composition of the geoseries": this presents the series that comprise the geoseries.

- "Form of the series": the shape of the series is either punctual, linear or extended [12].

\section{Metadata corresponding to the ecological variables}

The data regarding "reaction", "moisture", "nutrients", "light", "temperature" and "climate (i.e. continentality)" define the ecological conditions characterizing the tessela. They are based on indicator values defined by Ellenberg et al. (1992) and were calculated as follows: the value of Ellenberg's indicator is first calculated for each syntaxon in the study area on the basis of all the relevés composing the syntaxon. The synrelevé table is then transferred to the Juice program in which we manually enter the indicator value calculated for each syntaxon. In the second step, we use these values to calculate those of the synrelevé. In the example of synrelevé 22, composed of five syntaxa (see Table 1), the values of the indicators in the database correspond to the average values for the five syntaxa indicators. In this way, we can calculate the indicator value of each synrelevé, taking the vegetation cover into account. The indicator values will then be added in the "Paysage" database in order to characterize the ecological envelope of their tessela as follows:

- $\quad$ Soil reaction: from 1: hyper-acidiphilic to 9: basiphilic and calciphilic;

- $\quad$ Moisture: from 1: xerophilic to 9: hyper-eutrophic;

- $\quad$ Nutrients: from 1: dystrophic to 13: nitrophilic;

- $\quad$ Light: from 1: hyper-sciaphilic to 9: hyper-heliophilic;

- $\quad$ Temperature: from 1: cryophilic, alpine to snow to 9: hyper-thermophilic;

- $\quad$ Continentality: from 1: hyper-oceanic to 9: hyper-continental.

Other metadata can complement this ecological description of the tessela:

- $\quad$ Altitudinal belts;

- $\quad$ Geology: references the different types of rocks in the study area [6];

- $\quad$ Pedology: the list is the one provided in Baize et al. (2009);

- $\quad$ Altitude: the average altitude of the synrelevé;

- Aspects;

- Average slope.

\section{Use of the map}

An "Identifiant polygone GIS" was integrated into the basic structure of the "Paysage" database. The polygon corresponding to a synrelevé is created and the "Id" of the geometry is filled in, the information for which is also found in the corresponding entry in the "Paysage" database. All the information registered in the header data, as well as the list of the syntaxa composing a synrelevé, along with their abundance, can be displayed using the GIS and can be used for further requests (Figure 4). 

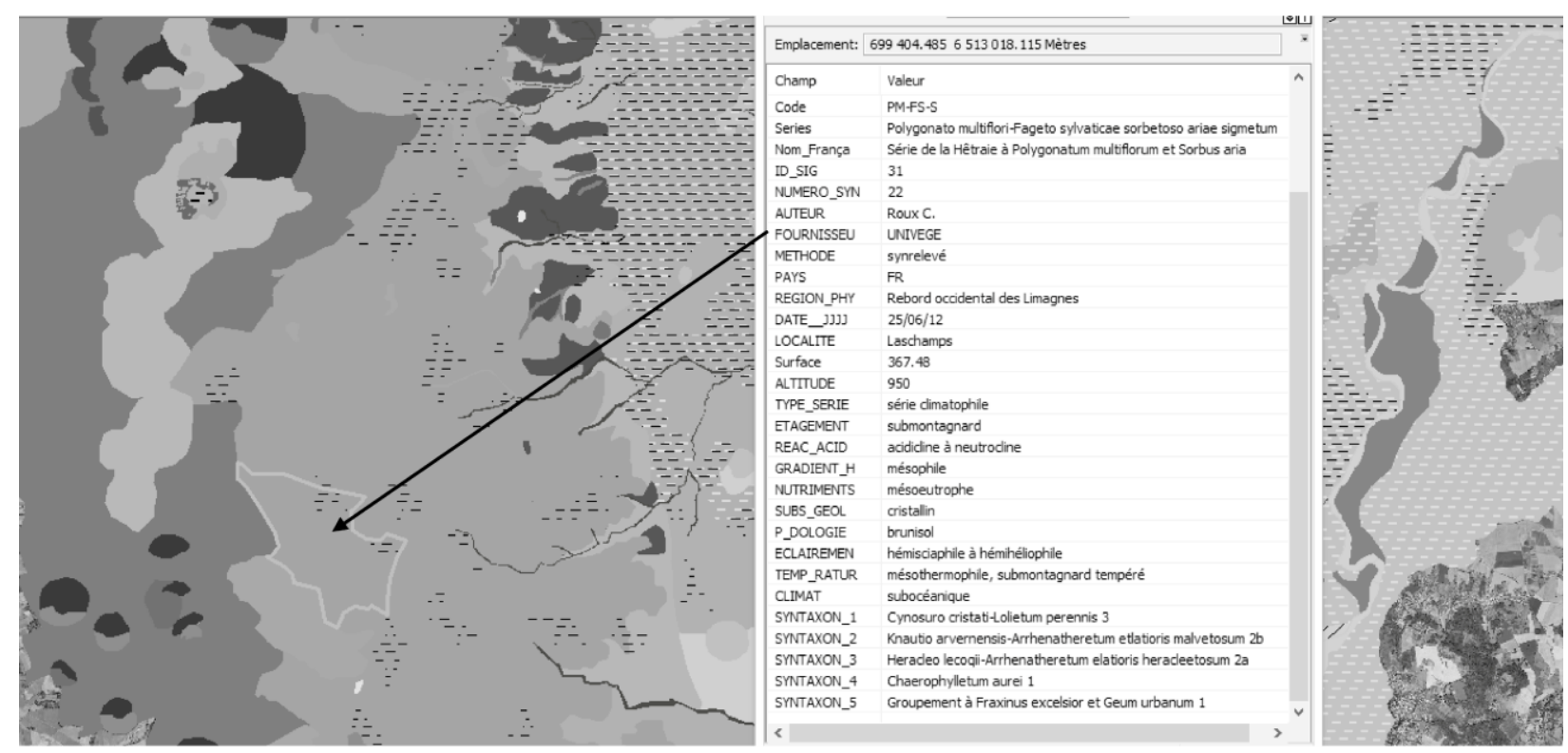

Fig. 4: Location of the polygon corresponding to synreleve 22 with its attribute information in the series map.

Use of the "Paysage" database for the diagnosis: an example of evaluating the degree of anthropogenic impact.

As shown in Figure 1 and Table 2, the synrelevés can be composed of syntaxa at a higher or lower degree of naturalness. When the anthropogenic impact increases, the expression of the ecological variables of the tessela tend to be minimized. For example, the high frequency of syntaxa typical of fertilized hay meadows in the synrelevé will increase the nutrient indicator level of the synrelevé and thereafter provide a diagnosis of the degree of (poor) naturalness of the synrelevé.

In Figure 5, the value of the Ellenberg indicator "nutrients" is shown for each of the 16 synrelevés of the beech wood Polygonatum multiflorum and Sorbus aria series. The light grey bar (A) and the black bar (B) represent the theoretical synrelevés, and the value corresponds to the theoretical Ellenberg values for the nutrients. The grey bar (A) represents the theoretical synreleve that is the most "natural" with no fertilization while the black bar (B) corresponds to the synrelevés resulting from vegetation changes under the influence of fertilization and anthropogenic actions. The data obtained for the 16 synrelevés carried out on the crystalline plateau in the study area is a series with mainly anthrogenic-related vegetation and only a few more natural types of vegetation. It should be noted that synrelevé 17, the most oligotrophic one, is comprised of only three syntaxa (Table 1): one related to grassland, one related to scrub vegetation and one related to a potential natural forest. Synrelevé 22, the most mesotrophic and anthropogenic synrelevé, contains five syntaxa: two hay meadows, one pasture, one nitrophilous herbaceous fringe and one substitution forest. This last synrelevé, with the highest community richness, reflects a greater anthropic impact; indeed, the number of associations composing a series of vegetation depends on the use of the landscape [4]. 


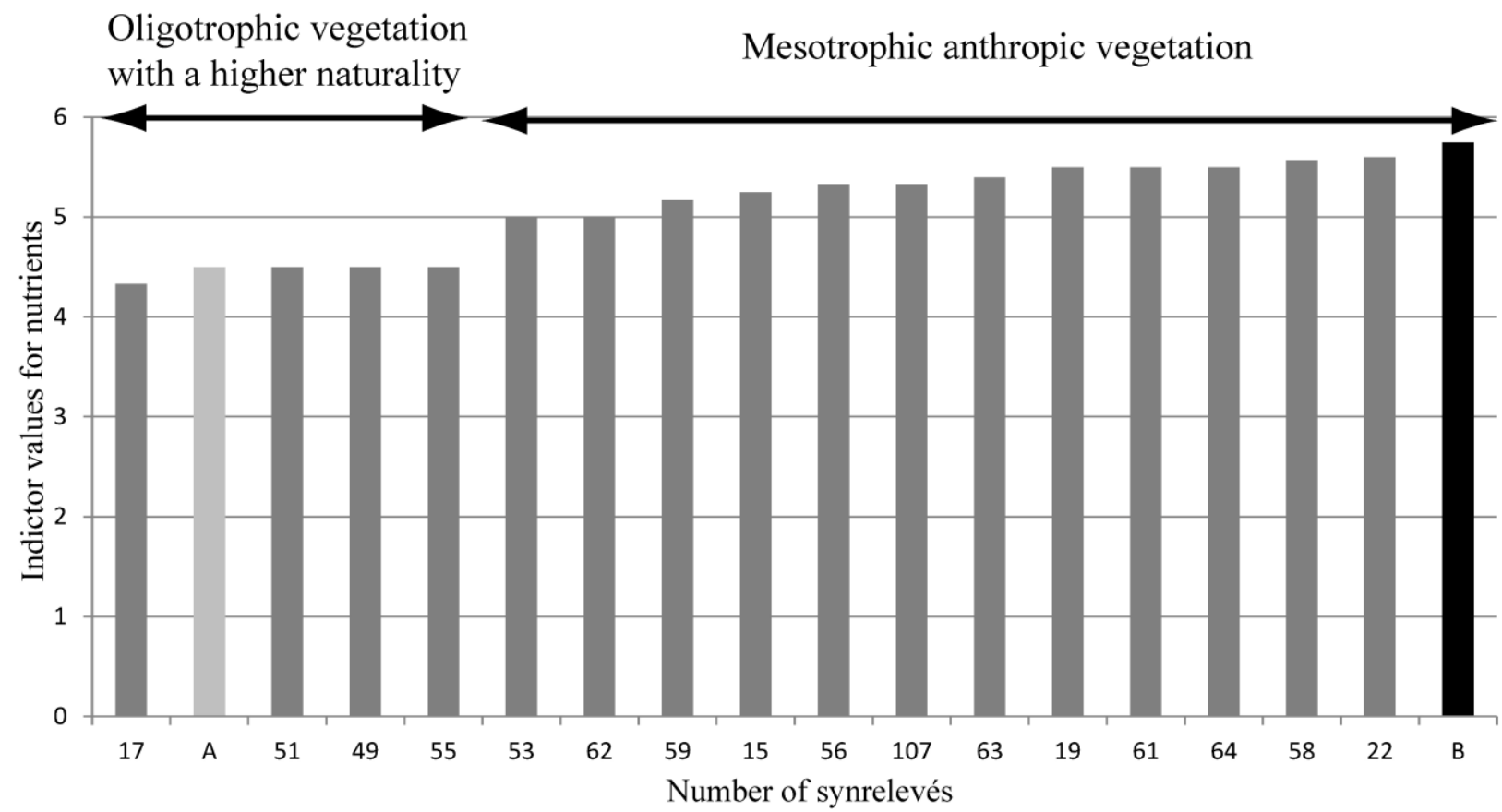

Fig. 5: Ellenberg "nutrients" values for the 16 synrelevés of the Polygonatum multiflorum and Sorbus aria beech wood series under natural or anthropic conditions. A and B: theoretical synrelevés.

\section{Perspectives}

Up until now, the "Paysage" database was used to describe vegetation within a limited geographical area. The "syntaxon" table will have to be completed with all the syntaxa listed for the French territory from the "Prodrome des Végétations de France" (PVF2, French phytosociological society, www.phytosocio.org). The standardization of the consultation tables needs to be improved and adjusted in order to address certain issues (e.g.: salinity in a littoral environment). The work in progress includes the description of the model for the "Paysage" database as well as a tutorial. The aim is that the VegFrance database will be soon be widely used to handle and exchange relevé data.

\section{REFERENCES}

1. Baize, D., Girard, M.-C., Association Française pour l'Etude du Sol, 2009, Référentiel pédologique 2008 [Soil repository 2008], Paris, Éditions Quae, Collection Savoir Faire.

2. Bardat, J., Bioret, F., Botineau, M., Boullet, V., Delpech, R., Géhu, J.-M., J. Haury, Lacoste, A., Rameau, J.-C., Royer, J.-M., Roux, G., Touffet, J., 2004, Prodrome des végétations de France [Prodrome vegetations of France], Paris, Publications Scientifiques du MNHN.

3. Biondi, E., Calandra, R., Gigante, D., Pignatelli, S., Rampiconi, E., Venanzoni, R., 2002, Il paesaggio vegetale della provincia di Tern [The plant landscape of the province of Terni], Terni, Università di Perugia, Arti grafiche Iezzi.

4. Biondi, E., 2011, Phytosociology today: methodological and conceptual evolution, Plant Biosystems, 145: 1929.

5. Bioret, F., Boullet, V., Choisnet, G., Roux, C., Thébaud, G., Panaïotis, C., Chalumeau, A., et al. "Landscape phytosociology concepts and definitions applied to serial and catenal vegetation mapping." Acta Botanica Gallica, soumis.

6. Boivin, P., Besson, J.-C., Briot, D., Camus, G., Goër de Herve, A., de Gourgaud, A., Labazuy, P., Langlois, E., Larouzière, F.-D. de, Livet, M., Mergoil, J., Miallier, D., Morel, J.-M., Vernet, G., Vincent, P.M.,. 2009, 
Volcanologie de la Chaîne des Puys [Volcanology of the Chaîne des Puys]. 5ème édition. Montlosier, Parc Naturel Régional des Volcans d'Auvergne.

7. Chytrý, M., 1998, Potential replacement vegetation: An approach to vegetation mapping of cultural landscapes, Applied Vegetation Science, 1: 177-188.

8. Dupias, G., Rey, P., 1985, Document pour un zonage des régions phyto-écologiques [Paper zoning phytoecological regions], Toulouse, Centre d'Ecologie des Ressources Renouvelables.

9. ECOBIO, VegFrance: https://vegfrance.univ-rennes1.fr

10. Ellenberg, H., Weber, H.E., Düll, R., Wirth, V., Werner, W., Paulßen, D., 1992, Zeigerwerte von Pflanzen in Mitteleuropa. 2. und verbesserte Auflage, Scripta Geobotanica, 18: 1-258.

11. Géhu, J.-M., 1974, Sur l'emploi de la méthode phytosociologique sigmatiste dans l'analyse, la définition et la cartographie des paysages [On the use of phytosociological sigmatiste method in the analysis, the definition and mapping of landscapes], Comptes Rendus de l'Académie des Sciences de Paris, 279 (D): 1167-1169.

12. Géhu, J-M., 1977, Le concept de sigmassociation et son application à l'étude du paysage végétal des falaises Atlantiques Françaises [The concept of sigmassociation and its application to the study of plant landscape of the French Atlantic cliffs], Vegetatio, 34 (2): 117-125.

13. Géhu, J.-M., 2006, Dictionnaire de sociologie et synécologie végétales [Dictionary of sociology and plant synecology], Stuttgart, J. Cramer.

14. Hennekens, S., Schaminée, J., 2001, TURBOVEG, a comprehensive data base management system for vegetation data, Journal of Vegetation Science, 12: 589-591.

15. Kovach, WL., 2010, MVSP: A MultiVariate Statistical Package for Windows: ver. 3.2. Pentraeth, Wales, U.K: Kovach Computing Services.

16. Lazare, J.-J., 2009, Phytosociologie dynamico-caténale et gestion de la biodiversité [dynamico-caténale phytosociology and biodiversity management], Acta Botanica Gallica, 156 (1): 46-61.

17. Loidi, J., Fernandez-Gonzalez, F., 2012, Potential natural vegetation: reburying or reboring?, Journal of Vegetation Science, 23: 596-604.

18. Pedrotti, F., 2013, Plant and vegetation mapping, Camerino, Springer.

19. Rivas-Martínez, S., 2005, Notions on dynamic-catenal phytososiology as a basis of landscape science, Plant Biosystems, 139 (2): 135-14.

20. Rivas Martínez, S., Navarro, G., Penas, Á., Costa, M., 2011, Biogeographic Map of South America. A preliminary survey, International Journal of Geobotanical Research, 1: 21-40 + map.

21. Schaminée, J., Hennekens, S., Ozinga, W., 2007, Use of the ecological information system SynBioSys for the analysis of large datasets, Journal of Vegetation Science, 18: 463-470.

22. Thébaud, G, Roux, C., Bernard, C.-E., Delcoigne, A., 2014, Guide d'identification des végétations du nord du Massif central: associations végétales et habitats naturels [Identification Guide to the north of the Massif central vegetation: plants and natural habitats associations], Clermont-Ferrand, Presses Universitaires Blaise Pascal.

23. Theurillat, J.-P., 1992, Étude et cartographie du paysage végétal (symphytocoenologie) dans la région d'Aletsch (Valais, Suisse) [Study and mapping of vegetation landscape (symphytocoenologie) in the Aletsch region (Valais, Switzerland)], Teufen, Commission géobotanique de l'Académie Suisse des Sciences Naturelles.

24. Tichý, L., 2002, JUICE, software for vegetation classification, Journal of Vegetation Science, 13: 451-453.

25. Trochet, J.-R., 2004, L'étude des paysages en France: éléments d'histoire [The study of landscapes in France : story elements], Belgeo, 2-3: 257-264.

26. Tüxen, R., 1956, Die heutige potentielle natürliche Vegetation als Gegenstand der Vegetationskartierung [Today's potential natural vegetation as the object of vegetation mapping], Angewandte Pflanzensoziologie, 13: $5-55$. 


\section{DESCRIEREA VEGETAȚIEI LA NIVEL DE PEISAJ: "PAYSAGE", O BAZĂ DE DATE DESTINATĂ SERIILOR ȘI GEOSERIILOR}

\section{(Rezumat)}

Proiectul CarHAB, finanțat de Ministerul Mediului francez, a fost destinat să cartografieze vegetația de pe întreg teritoriul Franței. Pentru aceasta s-au realizat atât relevee analitice, cât și sinrelevee. Pe baza studiului de caz de habitate montane joase din "chaine des Puys" (Masivul Central, Franța), acest articol prezintă: i) metodologia utilizată pentru realizarea releveelor de vegetație la nivelul peisajului și ii) baza de date existentă pentru a depozita sinreleveele, ca parte a bazei de date naţionale VegFrance.

Acest articol prezintă structura bazei de date "Paysage", metadatele colectate împreună cu comunitătile vegetale în sinrelevee (și geosinrelevee), metoda de înregistrare a sinreleveelor şi felul în care sunt utilizate pentru cartografierea seriilor și geoseriilor. De asemenea, se fac recomandări cu privire la presiunea antropică asupra peisajului. 